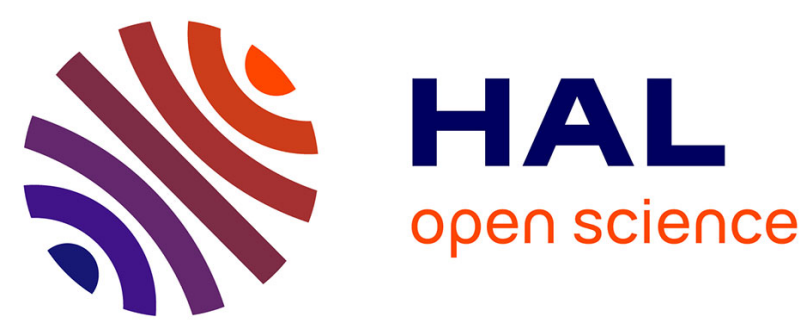

\title{
pH-CHEMFET-BASED ANALYSIS DEVICES FOR THE BACTERIAL ACTIVITY MONITORING
}

Marie Laure L Pourciel-Gouzy, Sandrine Assié-Souleille, Laurent Mazenq, Jérôme Launay, Pierre Temple-Boyer

\section{- To cite this version:}

Marie Laure L Pourciel-Gouzy, Sandrine Assié-Souleille, Laurent Mazenq, Jérôme Launay, Pierre Temple-Boyer. pH-CHEMFET-BASED ANALYSIS DEVICES FOR THE BACTERIAL ACTIVITY MONITORING. Sensors and Actuators B: Chemical, 2008, 134 (1), pp.339 - 344. 10.1016/j.snb.2008.04.029 . hal-01687854

\section{HAL Id: hal-01687854 \\ https://hal.laas.fr/hal-01687854}

Submitted on 18 Jan 2018

HAL is a multi-disciplinary open access archive for the deposit and dissemination of scientific research documents, whether they are published or not. The documents may come from teaching and research institutions in France or abroad, or from public or private research centers.
L'archive ouverte pluridisciplinaire HAL, est destinée au dépôt et à la diffusion de documents scientifiques de niveau recherche, publiés ou non, émanant des établissements d'enseignement et de recherche français ou étrangers, des laboratoires publics ou privés. 


\title{
pH-CHEMFET-BASED ANALYSIS DEVICES \\ FOR THE BACTERIAL ACTIVITY MONITORING
}

\author{
M.L. Pourciel-Gouzy, S. Assié-Souleille, L. Mazenq, \\ J. Launay, P. Temple-Boyer \\ LAAS-CNRS, University of Toulouse \\ 7 avenue du colonel Roche, 31077 Toulouse Cedex 4, FRANCE
}

\begin{abstract}
Silicon and polymer microtechnologies have been developed in order to integrate $\mathrm{pH}$ metry techniques in the frame of medical diagnosis. Thus, a fluidic analysis device has been designed and realised in order to monitor $\mathrm{pH}$-related bacterial activities. It includes a $\mathrm{SiO}_{2} / \mathrm{Si}_{3} \mathrm{~N}_{4} \mathrm{pH}$-sensitive chemical field effect transistor ( $\mathrm{pH}-\mathrm{ChemFET}$ ), its titanium/gold pseudo-reference gate electrode and a poly-dimethylsiloxane (PDMS) integrated flow-cell (total volume: $\leq 2 \mathrm{~mm}^{3}$ ). The whole analysis device has been used to detect the biological activities of the Lactobacillus Crispatus bacteria and to estimate its sensitivity to antibiotics. Results demonstrate the detection of $\mathrm{pH}$-related bacterial metabolisms in microvolumes, enabling to reduce significantly the analysis response time with regards to standard procedures and to think to the development of $\mathrm{pH}$-ChemFET-metry for medical analysis.
\end{abstract}

Keywords: pH-ChemFET, PDMS flow-cell microdevice, packaging, bacterial activity detection 


\section{Introduction}

As the demands of diagnostic laboratories continue to increase with the health costs rising, the necessity for rapid and cheap medical analysis has become increasingly apparent. The reduction in tissue or fluid sample volumes, the reduction in test reagent volumes, the high throughput of samples, the reduction of contamination and the ease of use increase through automation are all necessary elements to both reduce the cost of diagnostic tests and increase the speed in obtaining results. The implementation of miniaturized devices has begun to address such issues in all areas of laboratory testing, from sample preparation to sample reaction, separation and detection [1-2]. By miniaturizing the reaction chamber, less of the potentially infectious specimen is necessary and a faster reaction is possible decreasing drastically commonly used volumes. By miniaturizing the detection apparatus, less of reacted sample is necessary for measurement.

Many medical analyses are performed by monitoring $\mathrm{pH}$ variations occurring during various biochemical reactions. One of the most famous devices for routine identification of bacterial strains is the commercially available API diagnostic system (Biomérieux, FRANCE). It is very convenient and has today the most extensive range of detection available. It includes 15 identification systems covering practically all groups of bacteria and over 600 different species.

Historically, API 20 E® was the first identification system to be developed, combining a strip of biochemical tests and a database. The API 20 E strip consists of 20 micro tubes containing dehydrated substrates. These tests are inoculated with a bacterial suspension that reconstitutes the media. During incubation, bacteria metabolism (mainly pH-related) produces colour changes that are either spontaneous or revealed by the addition of reagents. The 
reactions are read according a known interpretation and the identification is obtained by referring to the Analytical Profile Index or using the identification software created by the manufacturer [3].

In all the API range, we are more particularly interested in API 50 CHL® kit dedicated to identification of Lactobacillus in 48 hours. However, the technique developed has some specific drawbacks. For example, before identification step, each strain must be isolated and grown on a specific medium. As soon as they become sufficiently numerous, they can be used as a bacterial suspension into API kit. Through biochemical reactions with this element (either an oxidation, either a fermentation), the bacteria cause a $\mathrm{pH}$ variation detected by a $\mathrm{pH}$ coloured indicator in the analysed medium. This process is well known, but is also time consuming, as 24 to 36 hours are needed to identify a bacterium thanks to its biochemical activities since a sample had been taken. To improve this technique, solutions are requiring the development of bio-fluidic micro devices for the $\mathrm{pH}$ monitoring of bacterial activities.

Within this framework, chemical field effect transistors (ChemFET) should offer innovative solutions as soon as a really convenient interface between microtechnologies and biotechnologies will be developed. As a first approach for on-line monitoring of cells metabolism, complex glass/silicon systems have been developed using flow-cell concepts, microfluidic devices and suitable microsensors [4-6]. In parallel, the development of bioreactors has emphasised the interest for the poly-dimethylsiloxane (PDMS) [7-11]. Indeed, this silicon gum elastomer is biocompatible as well as compatible with silicon technologies [12].

This paper deals with the adaptation of $\mathrm{pH}$-ChemFET microsensors for the detection of bacterial activity using a PDMS fluidic micro device. Through the large spectrum of medical tests, an interest was taken for the identification of glucose-fermenting gram-negative bacilli. Works have therefore been applied to a strain of Lactobacillus Crispatus bacterium and more 
precisely to the monitoring of different metabolisms related to different sugars and to resistance to antibiotics.

\section{Experimental}

A. Fabrication of $\mathrm{pH}-\mathrm{ChemFET} \mathrm{sensors}$

pH-sensitive chemical field effect transistors ( $\mathrm{pH}$-ChemFETs) were fabricated using LAAS-CNRS clean room facilities [13] on <100>-oriented N-type (500 $\Omega . c m$ ) silicon substrate. Insulation between the electrical active zones and the electrolyte involved a standard P-well technology, leading to the fabrication of $\mathrm{N}$-channel $\mathrm{pH}$-ChemFETs. A 50nm thermally grown $\mathrm{SiO}_{2}$ layer and a $50 \mathrm{~nm} \mathrm{Si}_{3} \mathrm{~N}_{4}$ layer deposited on top formed the $\mathrm{pH}$-sensitive gate structure. Finally, titanium/gold platings were deposited in order to integrate the pseudoreference gate. Thus, full $\mathrm{pH}-\mathrm{ChemFET}$ silicon chips (area: $5 \times 7 \mathrm{~mm}^{2}$ ) were realised.

B. Packaging of the $\mathrm{pH}-\mathrm{ChemFET}$ chip into the PDMS fluidic microstructures

All the fluidic microstructures were fabricated using the Sylgard 184 polydimethylsiloxane (PDMS) polymer, a commercially available product supplied by Dow Corning. This polymer was chosen for different reasons $[9,11]$. First, PDMS is biocompatible as well as inert with respect with the chemical and biological compounds used in our experiments. Also, PDMS naturally sticks to the silicon chip thanks to hydrogen bonding, and is therefore well adapted to the packaging of a silicon-based chip.

Our specifications and previous works made us give special attention to the development of a mass-fabrication process for the packaging of the $\mathrm{pH}$-ChemFET silicon 
chip into the PDMS fluidic microstructure. Another important requirement for us was, of course, a PDMS-related fabrication process fully compatible with classical microtechnology techniques. The whole process divides into three steps.

The first step consists in a classical thermo-molding of PDMS fluidic microstructures including different micro channels and micro tank. In that way, a PDMS prepolymer mixture was poured onto a SU-8 patterned silicon wafer. After curing the PDMS prepolymer for 10 min at $110^{\circ} \mathrm{C}$, the PDMS replicas were peeled off from the SU-8 patterned silicon wafer.

The second step concerns insertion of the pH-ChemFET chip into PDMS substrate (figure 2). To control the thickness of the PDMS deposit, we used a home-made support owning a 500 micrometers groove in its middle. This device has been realized onto a silicon wafer allowing us to deposit a negative photo resist by spin coating. Then, the ISFET chips are immediately put front side into the photo resist. At this point, PDMS mixture can be cast onto the chips stuck into the photo resist. After curing $\left(10 \mathrm{~min}\right.$ at $\left.110^{\circ} \mathrm{C}\right)$, the whole system is plunged into the photo resist developer. After photo resist dissolution, the PDMS including the ISFET chips can be peeled off from the silicon support. Thus, we obtain a large flat surface made both of PDMS and silicon nitride from the ISFET chip ready to host the previously molded microstructures.

So, finally, the third step consists in sealing the PDMS microstructures onto these PDMS layer supporting the sensor chip. This step is performed thanks to an oxygen plasma treatment of both PDMS/silicon parts. Special attention was brought to package fully the $\mathrm{pH}-$ ChemFET chip while keeping its $\mathrm{SiO}_{2} / \mathrm{Si}_{3} \mathrm{~N}_{4}$ sensitive gate and its $\mathrm{Ti} / \mathrm{Au}$ pseudo-refrence electrode uncovered. All these steps lead to the fabrication of an integrated analysis device for the $\mathrm{pH}$ monitoring in liquid phase (figure 2). 
C. Bacterial samples preparation

A suspension of a lyophilized strain of Lactobacillus Crispatus in sterilized saline (1\%, w/v) was spread on an MRS (De-Man, Rogosa, \& Sharpe, 1960) agar plate and incubated at $37^{\circ} \mathrm{C}$ for $48 \mathrm{~h}$. Some bacterial material was taken straight onto MRS agar plate to create a suspension in EDTA buffer (Tris-EDTA buffer solution, pH 7.4, FLUKA) during 10 minutes. This first washing was supposed to lead bacteria to eliminate all lactic acid accumulated during their growth. After buffer elimination thanks to centrifugation (5000 rpm, 1 minute), bacteria were washed again for 10 minutes in physiological saline solution.

At this point, the turbidity of the bacterial suspension was checked with VITEK Densichek (Biomérieux) for future adjustments by dilutions to match a McFarland 10 standard in saline solution. Afterwards, a new centrifugation step (5000 rpm, 1 minute) gives us the required bacterial residue for dissolution into the test solutions.

The test solutions consist in standard saline solution $\left([\mathrm{NaCl}]\right.$ at 9 g. $\left.\mathrm{L}^{-1}\right)$ alone or mixed with various sugars, i.e. glucose, fructose, xylose and sorbitol $\left(20\right.$ g.L $\left.\mathrm{L}^{-1}\right)$. Antibiotics-based solutions have also been tested. In that way, ampicillin has been used with various concentrations in saline solution containing glucose $\left(20 \mathrm{~g} \cdot \mathrm{L}^{-1}\right)$.

As soon as the bacterial residue is put in contact with the test solution, a $5 \mu \mathrm{L}$ drop is deposited at the entrance of the micro channel. There, the bacterial fluid is handled onto the sensitive gate through PDMS channels thanks to capillary forces (figure 3) and at this stage we can proceed to electrical characterization thanks to suitable probe measurements apparatus (figure 4). 
D. Measurements

Electrical characterisation was carried out by using the titanium/gold pseudo-reference electrode to apply the gate-source voltage $V_{G S}$ to the analysed solution. Chemical measurements were finally performed by I-V experiments, the gate-source voltage $V_{G S}$ variations being monitored for constant drain-source current IDS and drain-source voltage $V_{D S}$ $\left(\mathrm{IDS}=0.1 \mathrm{~mA}-\mathrm{V}_{\mathrm{DS}}=2 \mathrm{~V}\right)$. The $\mathrm{pH}-\mathrm{ChemFET}$ detection properties have been checked for solutions with various known $\mathrm{pH}$ (around 1, 4, and 7) enabling to define their detection sensitivity around $+50 \mathrm{mV} / \mathrm{pH}$. The " $+"$ sign indicates that a $\mathrm{pH}$ increase is responsible for an increase of the $\mathrm{pH}$-ChemFET threshold voltage $\mathrm{V}_{\mathrm{T}}$ and finally for an increase of the gatesource voltage $\mathrm{V}_{\mathrm{GS}}$ according to the chosen I-V monitoring (see below). In the following, since the $\mathrm{pH}$-ChemFET threshold voltage $\mathrm{V}_{\mathrm{T}}$ is known to be affected by non reproducible phenomenon for technological reasons, the gate-source voltage variations $\delta \mathrm{V}_{\mathrm{GS}}$ will be studied in order to establish clear comparisons between experiments.

\section{Results and discussion}

The first studies have been dedicated to the detection of a Lactobacillus Crispatus strain activity in presence of glucose. In order to do so, three experiments have been performed in a row (figure 5) by monitoring $\mathrm{pH}$ of different solutions with time:

A1-saline solution (0.9\%) and bacteria (10 McFarland), A2-saline solution $(0.9 \%)$ and glucose $\left(20\right.$ g. $\left.\mathrm{L}^{-1}\right)$, A3-saline solution $(0.9 \%)$, bacteria (10 McFarland) and glucose $\left(20\right.$ g. $\left.\mathrm{L}^{-1}\right)$. 
Whatever the experiments, a voltage increase is evidenced during the first minutes of analysis. This initial variation is not well explained since it is also seen for standard buffer solutions. It should be related to non-stabilities of the $\mathrm{pH}$-ChemFET threshold voltage during the initial wetting of the fluidic analysis system.

Nevertheless, after this initial phase, samples A1 and A2 show no real variations while the sample A3 is characterized by a voltage decrease around $150 \mathrm{mV}$, i.e. a $\mathrm{pH}$ decrease roughly from 7 to 4 . This phenomenon is well known: it is related to the consumption of glucose and the production of lactic acid by the Lactobacillus Crispatus bacteria. This phenomenon is controlled by the bacterial medium $\mathrm{pH}$ and leads to a $\mathrm{pH}$ steady-state regime around 4 for this kind of bacteria. First, those results clearly show the feasibility of this kind of measurement. Secondly, it is very important to notice the very short time of measurement, i.e. around 20 minutes, compared with conventional methods that require 12 or 24 hours. This method could make same-day reporting possible and thus permit better patient management.

To be closer to the previously named system API kit, the second studied was related to the bacteria affinity for different kind of sugars. For that, four solutions have been experimented in the same conditions, i.e. mixed with saline solution and bacteria (10 McFarland) (figure 6):

$$
\begin{aligned}
& \text { B1- glucose }\left(20 \mathrm{~g} . \mathrm{L}^{-1}\right) \text {, } \\
& \text { B2- fructose }\left(20 \mathrm{~g} . \mathrm{L}^{-1}\right) \text {, } \\
& \text { B3- sorbitol }\left(20 \mathrm{~g} . \mathrm{L}^{-1}\right) \\
& \text { B4- xylose (20 g.L. } \left.\mathrm{L}^{-1}\right) .
\end{aligned}
$$


Several studies with API $50 \mathrm{CH}$ system [14] showed that the Lactibacillus Crispatus strain is able to acidify both glucose and fructose but not xylose and sorbitol. This trend can clearly be observed on figure 6 where samples B1 and B2 are characterized by a fast voltage decrease related to the apparition of lactic acid. On the opposite and as expected, samples B3 and B4 do not show any significant variations. Once again, response times are very short compared with the one or two necessary days in case of classical used techniques.

Another advantage of such device lies in possibility to provide a qualitative side to this kind of measurement. Indeed, figure 7 proves that response is quite different following the bacteria concentration in solution. For that, we compared two samples based on a mix of saline solution $(0.9 \%)$ and glucose $\left(20\right.$ g.L $\left.\mathrm{L}^{-1}\right)$ :

\section{C1- bacteria (5 McFarland) \\ C2- bacteria (10 McFarland)}

For the twice more concentrated solution $\mathrm{C} 2$, the voltage decrease is still evidenced, leading to the steady-state $\mathrm{pH}$ value (around 4) in barely 40 minutes. For the less concentrated solution $\mathrm{C} 1$, a transitive $\mathrm{pH}$ (around $\mathrm{pH} 6$ regarding detection sensitivity around $+50 \mathrm{mV} / \mathrm{pH}$ ) is only reached during the same duration. From these results, it appears that the $\mathrm{pH}$ decrease kinetics is directly related to the bacteria concentration, i.e. to the bacterial global activity.

Comparing the whole results (figures 6 to 8), it also appears some differences of reaction times for the same kind of experiment since those times fluctuate between 15 and 40 minutes. Those kinetic modifications are certainly due to several factors that have not been fully controlled during these first experiments: bacteria culture age, bacteria strains multiplicity and temperature. The response time variations should therefore be related to uncontrolled discrepancy of bacterial global activity (for a constant bacterial turbidity). 
Finally, thinking to the antibiograms application, the influence of a given antibiotic on bacterial metabolism has been studied using the developed bio-fluidic analysis devices. Five samples have been tested for comparison. In a mixed solution of saline solution, glucose (20 g.L $\left.\mathrm{L}^{-1}\right)$ and bacteria (10 McFarland) various concentrations of ampicillin were added:
D1- blank solution
D2- ampicillin at $100 \mu \mathrm{g} \cdot \mathrm{mL}^{-1}$
D3- ampicillin at $500 \mu \mathrm{g} \cdot \mathrm{mL}^{-1}$
D4- ampicillin at $2500 \mu \mathrm{g} \cdot \mathrm{mL}^{-1}$
D5- ampicillin at $5000 \mu \mathrm{g} \cdot \mathrm{mL}^{-1}$

As expected, it appears that the ampicillin antibiotic has a direct influence on the Lactobacillus Crispatus metabolism of glucose (figure 8). As the ampicillin concentration increases, the $\mathrm{pH}$ decrease is strongly attenuated, evidencing the bacterial activity inhibition in a somewhat qualitative way. Indeed, according to the literature [15], we are also able to evidence different behaviours with the antibiotic concentrations. And, moreover, we are able to estimate the ampicillin inhibition threshold between 500 and $2500 \mu \mathrm{g} / \mathrm{mL}$, result which can be likened to the classical minimal inhibitory concentration (MIC). The MIC parameter is defined as the lowest antibiotic concentration that inhibits the visible bacterial growth. It has been estimated around $10 \mu \mathrm{g} / \mathrm{mL}$ for our Lactobacillus Crispatus strain by using standard bacterial macro-analysis on a solid medium. The divergence concerning the MIC values lies on the differences between analysed volumes and bacteria concentrations: 100 to 500 microliters and 0.5 McFarland for broth media or solid media as agar [15,16] compared to 5 microliters and 5 to 10 standard McFarland for our fluidic devices. 
However, our system has shown some drawbacks linked to the PDMS elastomeric nature. Indeed, expansions and contractions of the channels due to applied pressures during fabrication process can lead to the apparition small gaps between sensor chip and polymer which are responsible for liquid micro-leaks. In that case, we have witnessed drift phenomena of the $\mathrm{pH}$-ChemFET sensor, leading finally to disturbances of the system response. Moreover, the proposed fabrication/packaging process (as described on figure 1) is done at the chip level. This induced an important workload attending that only few chips can be packaged at the same time. To avoid this kind of troubles, we finally looked for a way to proceed at the wafer level and to package the chips in a collective way with the fewer technological steps possible. Aiming to such goal, we have focused onto the SU-8 photo resist which is already commonly used to designed micro fluidic devices [17]. An innovative photolithography technique was used to design micro channels embedded into SU-8 photo resist straight onto a silicon wafer using only one photolithography step (figure 9). This technique was experimented by creating micro channels with various dimensions ranging from $100 \mu \mathrm{m}$ to $1000 \mu \mathrm{m}$ wide and $1 \mathrm{~mm}$ to $2 \mathrm{~mm}$ long. The height of the channels was fixed to $450 \mu \mathrm{m}$.

Since capillary forces are used to handle fluids into micro channels, fluid velocity measurements have been performed both in PDMS and SU-8 microdevices for comparison. A water-based solution of polyvinyl alcohol (PVA) has been chosen for test. Polyvinyl alcohol (PVA) is a well-known colourless, water-soluble and flammable organic polymer [18]. According to our supplier (PCAS society Longjumeau - FRANCE), pure PVA (PVA SPP-H13) contains about $87 \%$ of water and is characterised by a volumic mass around 1.001 and a viscosity around 8 Pa.s. It has therefore been mixed into water (ratio: 1/1) to reach an intermediary viscosity of $240 \times 10^{-3}$ Pa.s. 
Except for its viscosity, the PVA/water mixture has been considered practically equivalent to an aqueous solution. One drop of fluid was deposited at the entrance thanks to a syringe and liquid progress was filmed using a high resolution CCD camera. Acquisition was immediately done onto PC and fluid displacement length was measured frame after frame and plotted as a function of time (figure 10). Results show clearly that capillary forces are more efficient into the SU-8 microdevice rather than into the PDMS one. It should be mentioned that similar experiments have been performed for pure water (viscosity: $10^{-3} \mathrm{~Pa} . \mathrm{s}$ ). In this case, the fluid displacement into the SU-8 microdevice was too fast to be measured with our measurement procedure. Indeed, the whole $2 \mathrm{~mm}$-long SU-8 microchannel was travelled in less than 1/30 second (one video frame) for an average velocity above $50 \mathrm{~mm} \cdot \mathrm{s}^{-1}$ (versus a 4 $\mathrm{mm} \cdot \mathrm{s}^{-1}$ average velocity for the $2 \mathrm{~mm}$-long PDMS microchannel). Those measurements allow us to be very confident about the use of this SU-8 process for collective fabrication of our micro biological application.

\section{Conclusion}

A pH-ChemFET-based fluidic analysis device has been successfully developed using silicon and polymer, i.e. poly-dimethylsiloxane (PDMS), technologies for the bacterial activities monitoring into small volumes $\left(\sim 1 \mathrm{~mm}^{3}\right)$. Demonstration has been performed through the characterisation of Lactobacillus Crispatus strains. Thus, using capillary forces to motion liquid biological samples, the bacteria main metabolisms have been studied by $\mathrm{pH}$ ChemFET-metry techniques: consumption of specific sugars (glucose and fructose) responsible for lactic acid production, inertness of non-specific sugars (xylose and sorbitol), influence of the bacteria concentration on response kinetics, inhibition of bacterial activity with antibiotic, i.e. ampicillin, concentration. Results have also evidenced low response time, 
around half an hour to be compared to more than ten hours for standard measurement techniques using $\mathrm{pH}$ indicator, as well as the possibilities of quantitative measurements for the bacterial concentration or the antibiotics minimal inhibitory concentration (MIC).

However, experiments have also shown some technological drawbacks leading to nonreproducibility of measurement, temporal drift, low lifetime and/or low fabrication yield. Some of them, related to the silicon-based ChemFET technology, can be tackled off through the development of adapted calibration technique. In order to solve the others drawbacks related to the PDMS-based technology, packaging process has to advance from the chip level to the wafer level. In order to do so, first technological realisations have been developed using SU8-based technology. Thus, experimental results have demonstrated the collective fabrication of SU8-made, integrated microchannels and microtanks, and the use of capillary force for the liquid biological samples motion into such fluidic microdevices

These pH-ChemFET-based fluidic analysis devices will be further studied for the bacterial activities monitoring. Works will concern the understanding of the Lactobacillus Crispatus $\mathrm{pH}$-related bacterial metabolism into microvolume, and will be also extended to the characterization by $\mathrm{pH}-\mathrm{ChemFET}$-metry of other (pathogen...) bacteria in the field of medical analysis and more especially for antibiograms applications.

\section{Acknowledgements}

We would like to thank Pr. Lepargneur from the CEDIBIO medical laboratory (Toulouse - France) for supplying the Lactobacillus Crispatus strains, the different sugars and the antibiotics as well as the ELITECH society (Puteaux - France) for the financial support. 


\section{References}

[1] MA Shoffner, J Cheng, GE Hvichia, LJ Kricka, P Wilding: "Chip PCR. I. Surface passivation of microfabricated silicon-glass chips for PCR", Nucleic Acids Research, 24 (1996), 375-379

[2] A. van Belkum: "Molecular diagnostics in medical microbiology: yesterday, today and tomorrow", Current Opinion in Pharmacology, 3, (2003), issue 2, 497-501

[3] http://www.biomerieux-diagnostics.com/servlet/srt/bio/clinical$\underline{\text { diagnostics/dynPage?doc=CNL_PRD_CPL_G_PRD_CLN_11 }}$

[4] M. Lehmann, W. Baumann, M. Brischwein, R. Ehret, M. Kraus, A. Schwinde, M. Bitzenhofer, I. Freund, B. Wolf: "Non-invasive measurement of cell membrane associated proton gradients by ion-sensitive field effect transistor arrays for microphysiological and bioelectronical applications ", Biosensors and Bioelectronics, 15 (2000), 117-124

[5] M.C. Acero, A. Errachid, T. Baldi, R. Perez-Castillejos, J. Esteve, N. Garcia, T. DiezCaballero: "Differential injection analysis based on ISFET sensors", Proceedings of the Eurosensors XIV conference, Copenhagen, Danemark, (2000)

[6] M.L. Pourciel-Gouzy, W. Sant, I. Humenyuk, L. Malaquin, X. Dollat, P. Temple-Boyer: "Development of pH-ISFET sensors for the detection of bacterial activity", Sensors and Actuators, B103, (2004), 247-251

[7] J.R. Anderson, D.T. Chiu, J.C. Mac Donald, R.J. Jackman, O. Cherniavskaya, H. Wu, S. Whitesides, G.M. Whitesides: "Fabrication of topological complex three-dimensional microfluidic systems in PDMS by rapid prototyping", Anal. Chem., 72 (2000), 3158-3164

[8] M. Powers, K. Domansky, A. Udapadhia, M. Kazempur-Mofrad, P. Kursawky, W.K. Janigan, D. Stolz, R. Kamm, L. Griffith: "A microarray perfusion bioreactor for 3D liver culture", Biotechnol. Bioeng., 78 (2001), 257-269 
[9] J.T. Borenstein, H. Terai, K. King, C. Weinberg, M. Kazempur-Mofrad, J.P. Vacanti: "Microfabrication technology for vascularized tissue enginering", Biomed. Microdev., 4 (2002), 167-175

[10] L. Malaquin, C. Vieu, "Using PDMS as thermocurable resist for a molded assisted imprint process" to be published in "Alternative Lithography" - Book Series on Nanostructure Science and Technology - In: David. J. Lockwood, NRC Ottawa, Canada Eds - Kluwer Academic / Plenum Publishers

[11] D. Juncker, H. Schmid, A. Bernard, I. Caelen, B. Michel, N. De Rooij, E. Delamarche. "Soft and rigid two-level microfluidic networks for patterning surfaces", J. Micromech. Microeng, 11 (2001) 532-541

[12] D.J Martin, L.A Warren, P.A Gunatillake, S.J McCarthy, G.F. Meijs, K. Schindhelm. Polydimethylsiloxane/polyether-mixed macrodiol-based polyurethane elastomers: biostability, Biomaterials 21 (2000), 1021-1029

[13] P. Temple-Boyer, J. Launay, I. Humenyuk, T. Do Conto, A. Martinez, C. Bériet, A. Grisel: "Study of front-side connected chemical field effect transistor for water analysis", Microelectronics Reliability, 44, (2004), 443-447

[14] M.A. Boyd May, A.D. Antonio, S.L. Hillier: "Comparison of API $50 \mathrm{CH}$ Strips to Whole-Chromosomal DNA Probes for Identification of Lactobacillus Species”, J. Clinical Microbiology, 43 (2005), 5309-5311

[15] J.A. Simoes, A.A. Aroutcheva, S. Shott, S. Faro: "Effect of metronidazole on the growth of vaginal lactobacilli in vitro", Infect Dis Obstet Gynecol, 9(1) (2001) 41-45

[16] M.R. D'Aimmo, M.Modesto, B.Biavati : "Antibiotic resistance of lactic acid bacteria and Bifidobacterium spp. isolated from dairy and pharmaceutical products", International Journal of Food Microbiology, 115(1), (2007), 35-42 
[17] Y.J. Chuang, F.G. Tseng, J.H. Cheng, W.K. Lin: "A novel fabrication method of embedded micro-channels by using SU-8 thick-film photoresists", Sensors and Actuators, 103(1-2), (2003), 64-69

[18] M.L. Pourciel, J. Launay, W. Sant, V. Conédéra, A. Martinez, P. Temple-Boyer: "Development of photo-polymerisable polyvinyl alcohol for biotechnological applications", Sensors and Actuators, B94, (2003), 330-336

\section{Biographies}

Marie-Laure Pourciel-Gouzy was born on July 25, 1976. She received her Master's Degree in physics from the Université Paul Sabatier de Toulouse (France) in 1999 and her Diplome d'Etudes Approfondies in Biotechnology from the Institut National des Sciences Appliquées de Toulouse (France) in 2000. She joined the Laboratoire d'Architecture et d'Analyse des Systèmes of the French Centre National de la Recherche Scientifique (LAAS-CNRS) in 2000 and received the $\mathrm{PhD}$ degree the Institut National des Sciences Appliquées de Toulouse (France) in 2004. Since then, she has been working on the development of pH-ISFET-metry deviated techniques for medical applications.

Sandrine Assié-Souleille was born the 15 September 1975. She joined the Laboratoire d'Architecture et d'Analyse des Systèmes from the French Centre National de la Recherche Scientifique (LAAS-CNRS) in 2002. She is working as an engineer in instrumentation and development. 
Laurent Mazenq was born on May 30, 1982. He joined the Laboratoire d'Architecture et d'Analyse des Systèmes of the French Centre National de la Recherche Scientifique (LAASCNRS) in 2002. Since then, he has been working on photolithography and on micronanotechnologies process realisation.

Pierre Temple-Boyer was born on October 25, 1966. He received his Engineer Master's Degree in electronic engineering from the Ecole Supérieure d'Electricité (Paris - France) in 1990 and his Master's Degree in microelectronics from the Université Paul Sabatier de Toulouse (France) in 1992. He joined the Laboratoire d'Architecture et d'Analyse des Systèmes of the French Centre National de la Recherche Scientifique (LAAS-CNRS) in 1992 and received the $\mathrm{PhD}$ degree from the Institut National des Sciences Appliquées de Toulouse (France) in 1995. Since then, as a senior researcher, he has been working on the development of micro- and nanotechnologies. 


\section{FIGURE CAPTIONS}

Figure 1: pH-ChemFET chip embedding process in PDMS

Figure 2: pH-ChemFET chip embedded into PDMS

Figure 3: Bacterial fluid handling into PDMS micro channel and filling of the $1 \mu \mathrm{L}$ micro tank

\section{Figure 4: Characterization apparatus}

Figure 5: Gate-source voltage VGS variations versus time for various test solutions, SS: Saline Solution (0.9\%) LB: Lactobacillus Crispatus strain G: Glucose (20 gL $\left.\mathrm{gL}^{-1}\right)$

Figure 6: Gate-source voltage VGS variations versus time for different kind of sugar assimilation by a Lactobacillus Crispatus strain - G: Glucose, F: Fructose, S: Sorbitol and X: $\underline{\text { Xylose (concentration for all sugars } 20 \text { g.L.- }{ }^{-1} \text { ) }}$

Figure 7: Gate-source voltage VGS variations versus time for two bacteria concentrations (5 and $10 \mathrm{McFarland})$ with glucose addition $\left(20 \mathrm{~g} . \mathrm{L}^{-1}\right)$

Figure 8: Gate-source voltage VGS variations versus time during glucose assimilation in presence of ampicillin (A) for a Lactobacillus Crispatus strain

Figure 9: New SU8 microstructures 
Figure 10: PVA/water mixture (viscosity $: 240.2 \times 10^{-3} \mathrm{Pa.s}$ ) travelled distance as a function of time, comparison between the PDMS and SU-8 microchannels. 

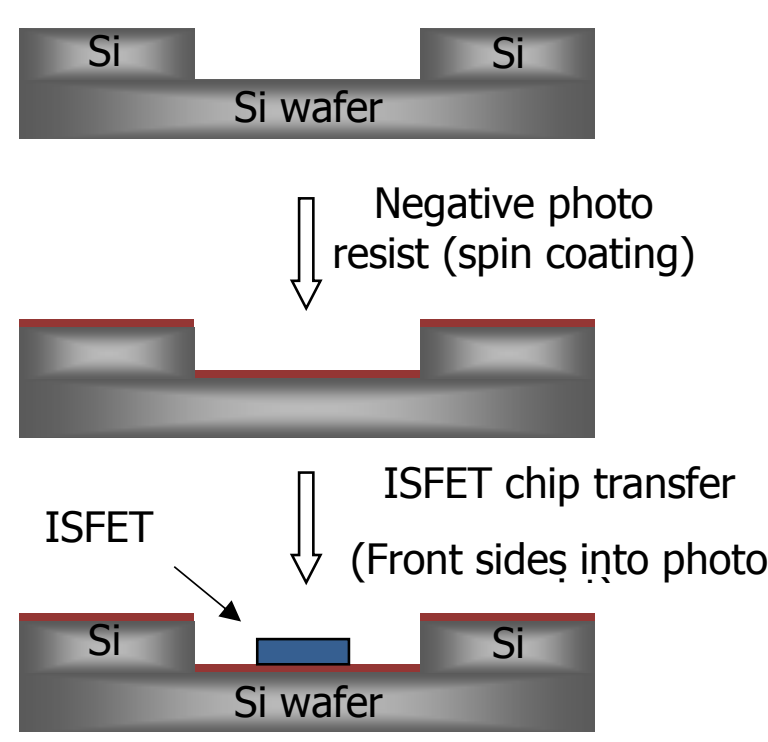
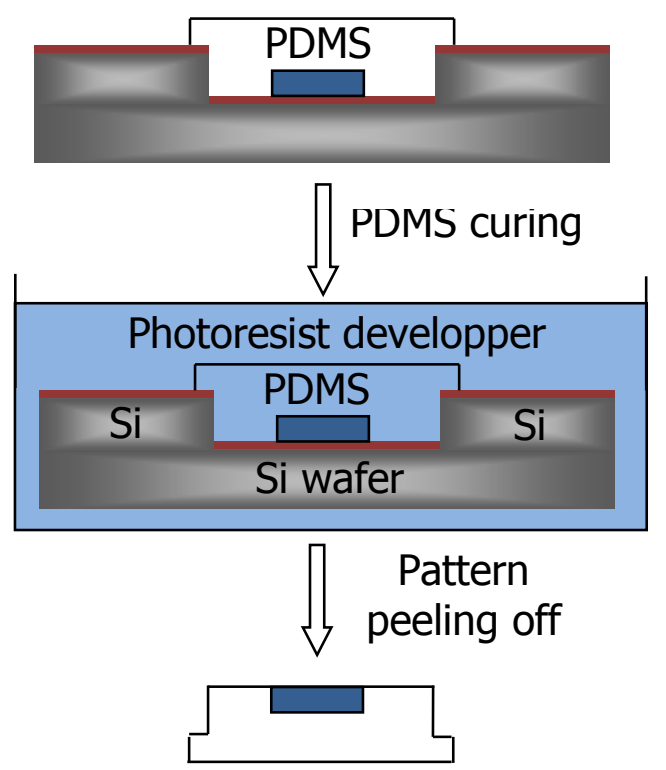

Figure 1: pH-ChemFET chip embedding process in PDMS 


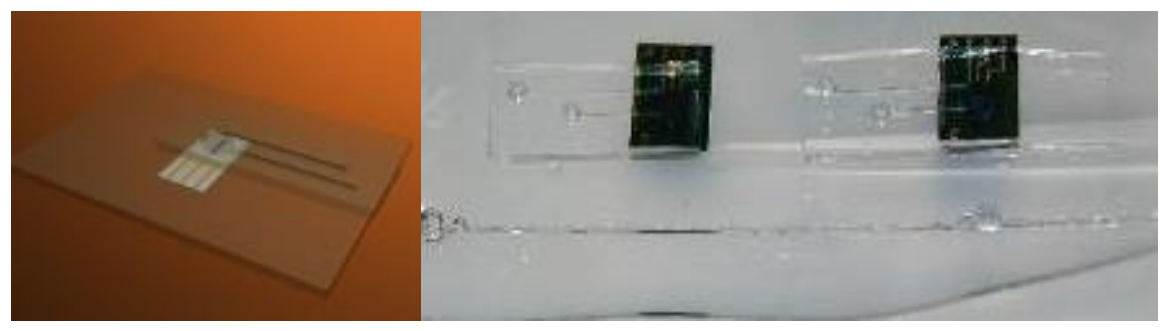

Figure 2: $\mathrm{pH}-\mathrm{ChemFET}$ chip embedded into PDMS 


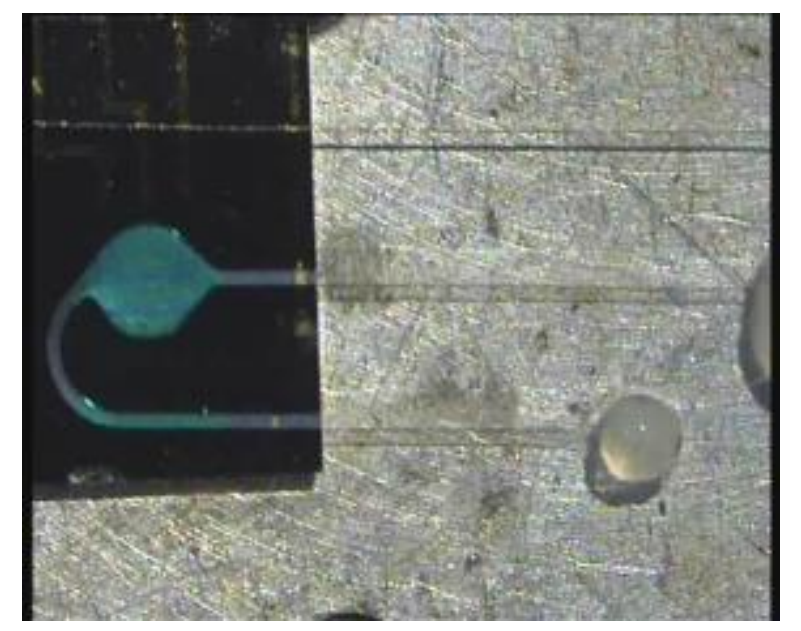

Figure 3: Bacterial fluid handling into PDMS micro channel and filling of the $1 \mu \mathrm{L}$ micro tank 


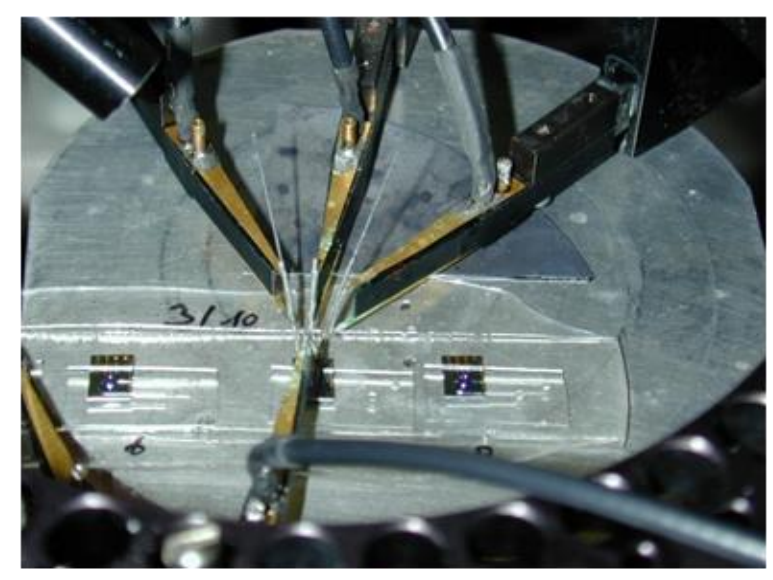

Figure 4: Characterization apparatus 


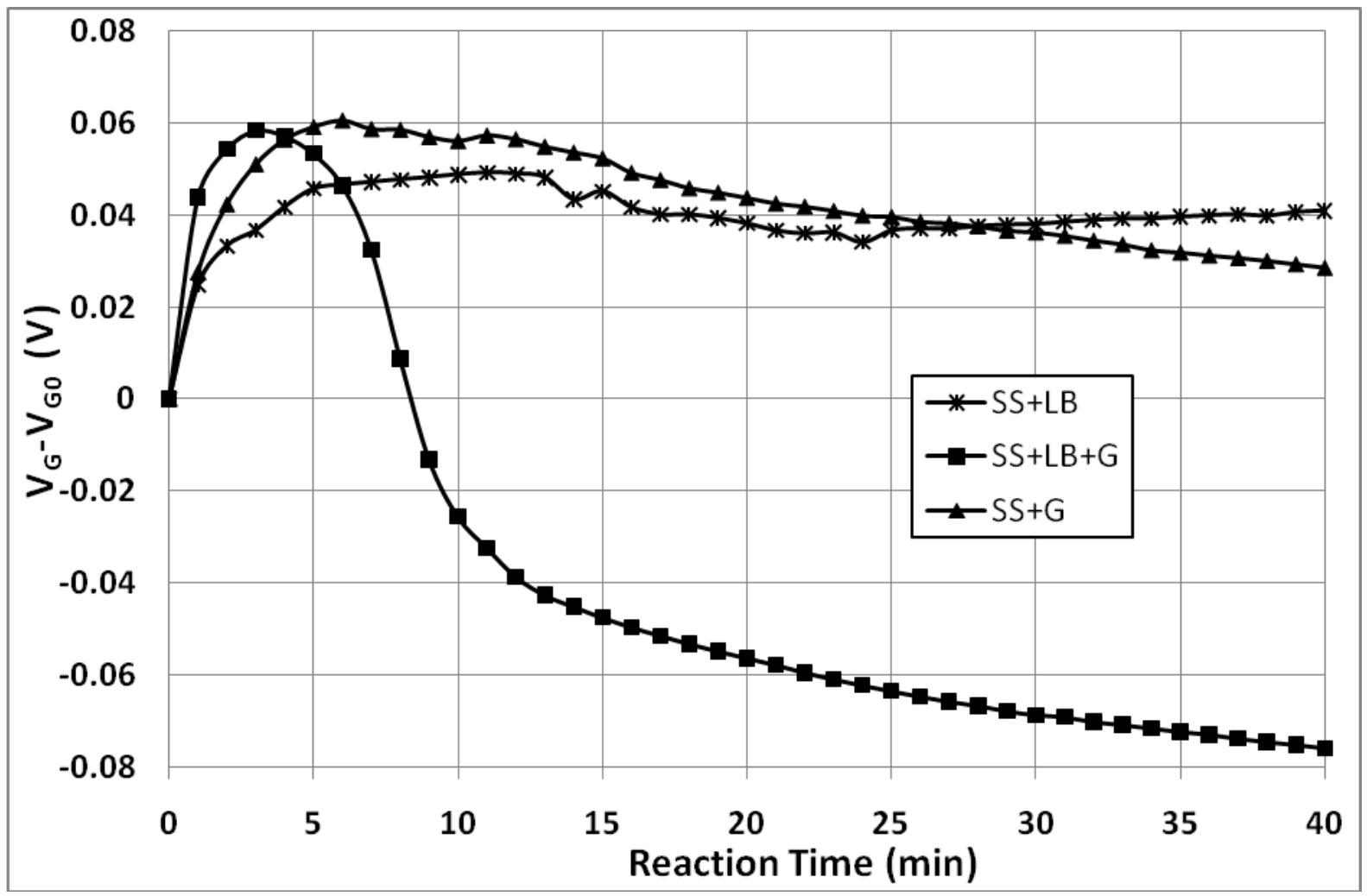

Figure 5: Gate-source voltage VGS variations versus time for various test solutions, SS: Saline Solution (0.9\%) LB: Lactobacillus Crispatus strain G: Glucose (20 $\left.\mathrm{gL}^{-1}\right)$ 


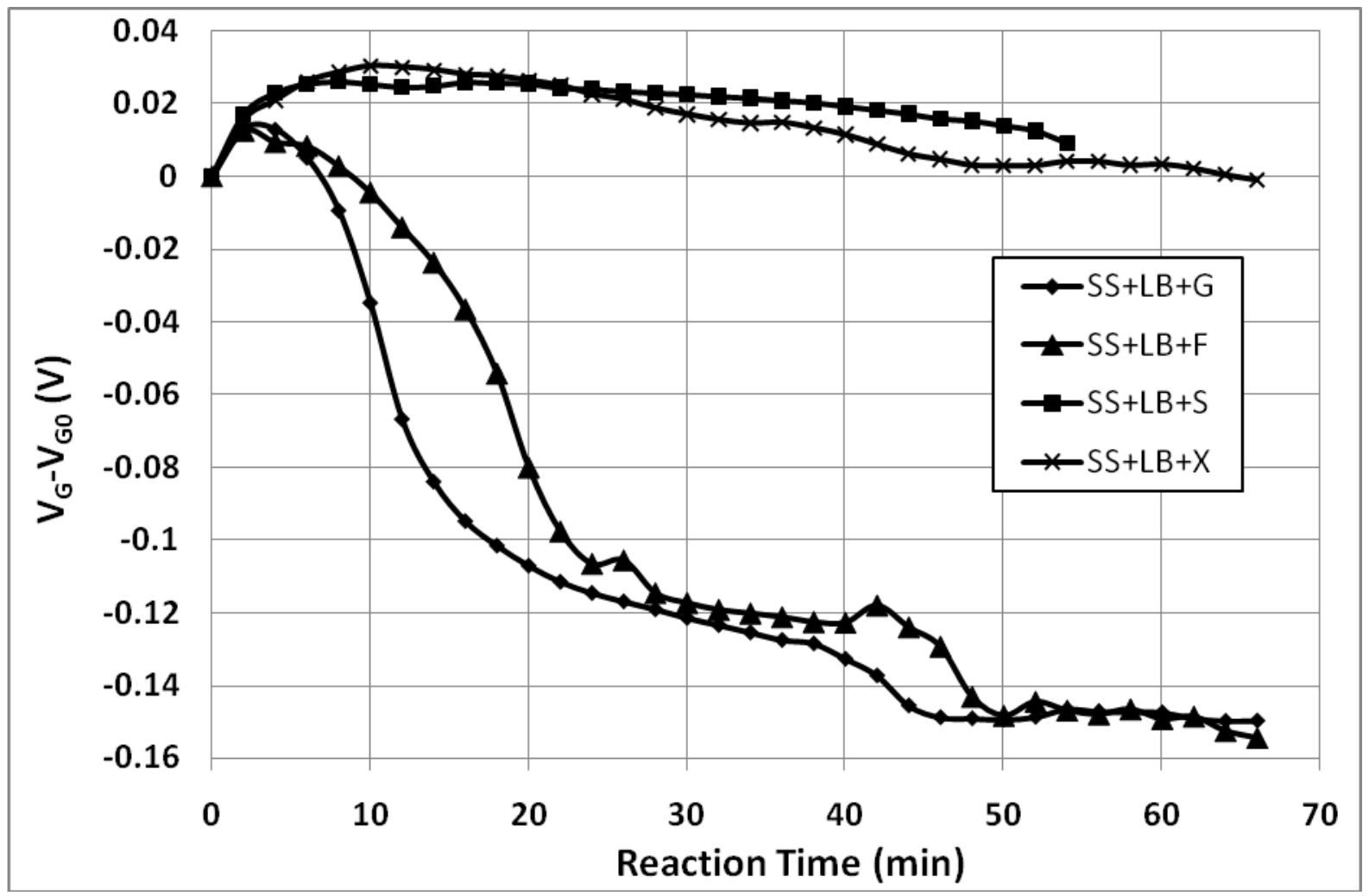

Figure 6: Gate-source voltage VGS variations versus time for different kind of sugar assimilation by a Lactobacillus Crispatus strain - G: Glucose, F: Fructose, S: Sorbitol and X: $\underline{\text { Xylose (concentration for all sugars } 20 \text { g.L. } \mathrm{L}^{-1} \text { ) }}$ 


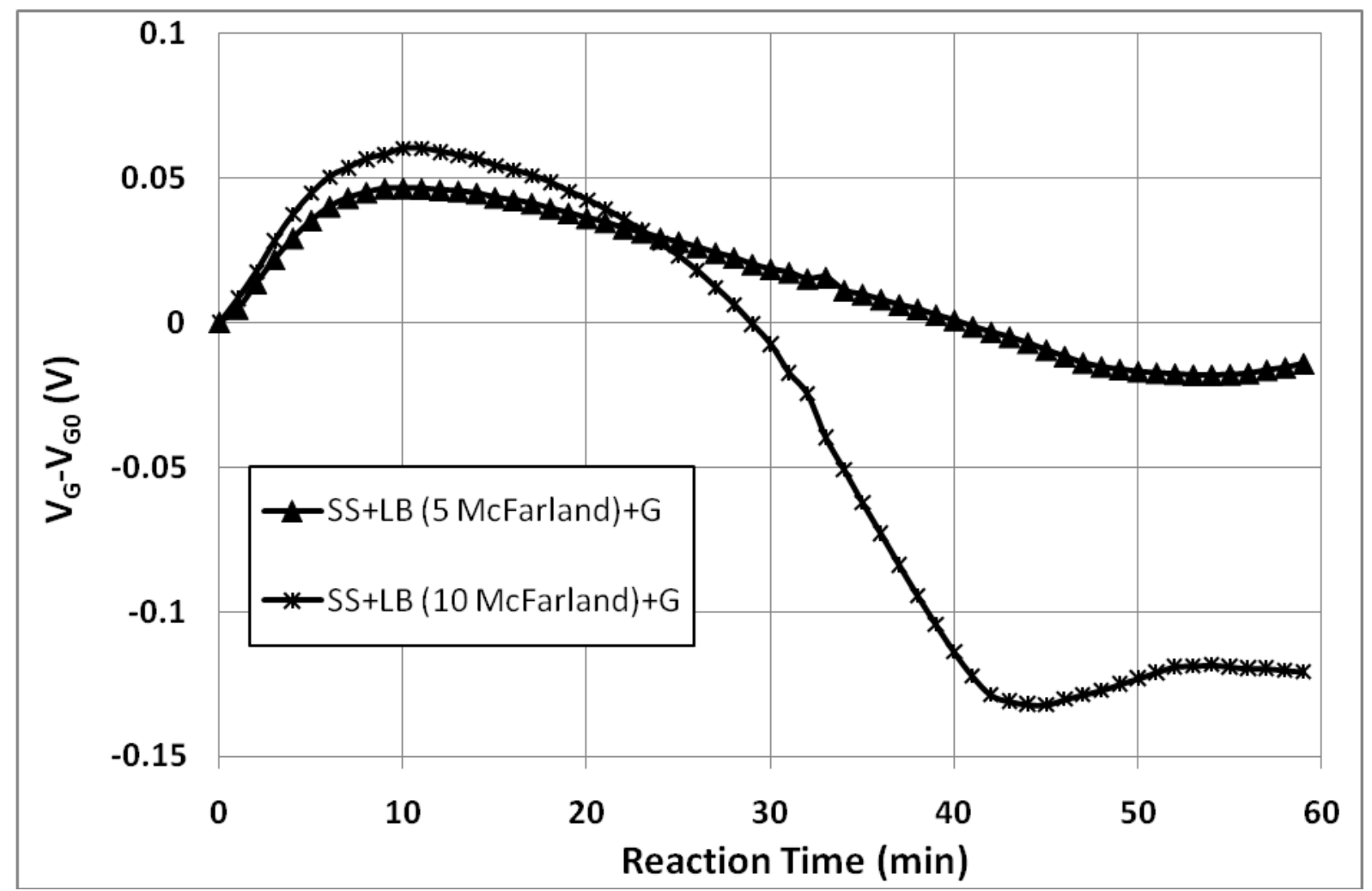

Figure 7: Gate-source voltage VGS variations versus time for two bacteria concentrations (5 and $10 \mathrm{McFarland})$ with glucose addition $\left(20 \mathrm{~g} . \mathrm{L}^{-1}\right)$ 


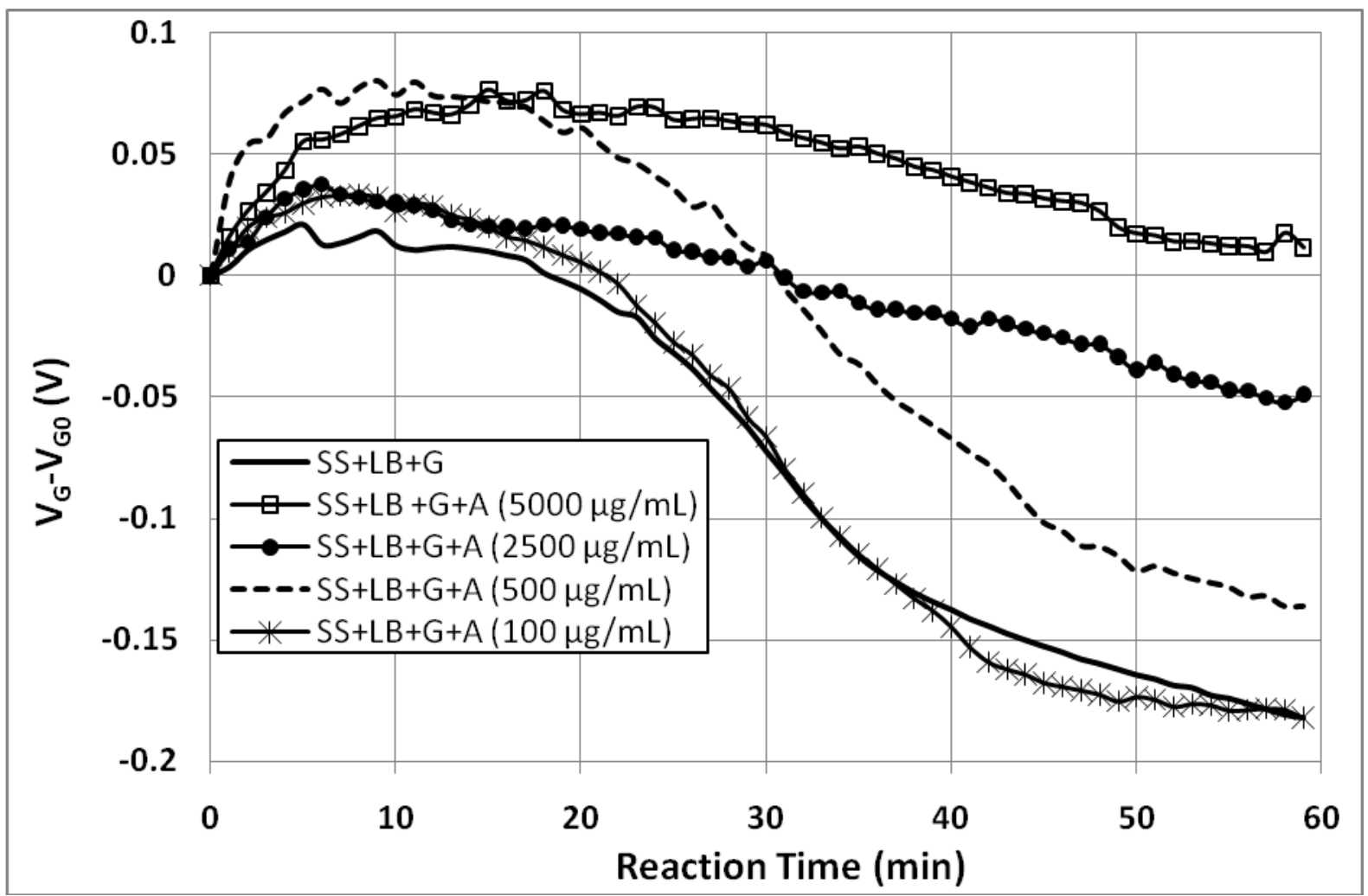

Figure 8: Gate-source voltage VGS variations versus time during glucose assimilation in presence of ampicillin (A) for a Lactobacillus Crispatus strain 


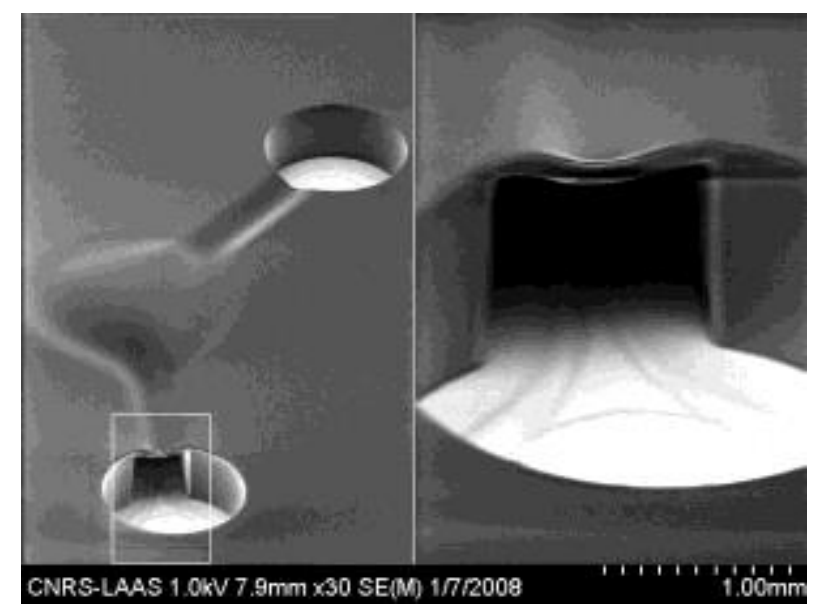

Figure 9: New SU8 microstructures 


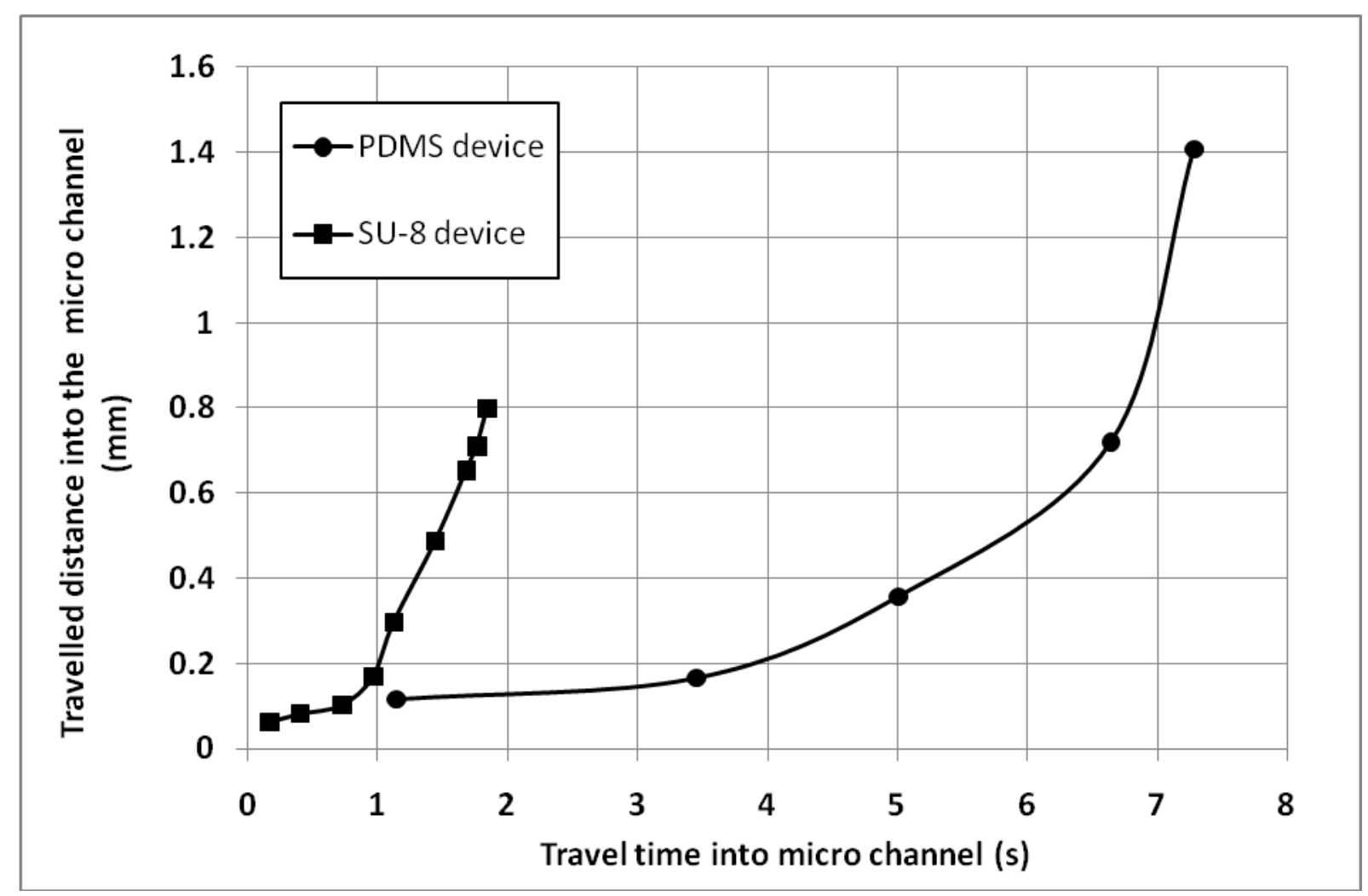

Figure 10: PVA/water mixture (viscosity $: 240.2 \times 10^{-3} \mathrm{~Pa} . \mathrm{s}$ ) travelled distance as a function of time, comparison between the PDMS and SU-8 microchannels. 